\title{
THE EFFECT OF AUTHENTIC LEADERSHIP ON JOB STRESS
}

\author{
OTANTIKK LİDERLİĞİN İȘ STRESINNE ETKİSİ
}

\author{
Murat SAĞBAŞ ${ }^{1}$ - Cem KARABAL ${ }^{2}$ - Lütfi SÜRÜC $\ddot{U}^{3}$
}

\begin{abstract}
The uncertainties experienced in the tourism sector together with the Covid-19 pandemic have created an important source of stress on the employees. In order to increase service quality and ensure organizational success, this stress on employees must be reduced. In the research, the effect of the authentic leadership, which motivates the employees in such chaotic environments, was investigated. In accordance with the research purpose, a questionnaire was applied to hotel employees in the Alanya $(n=311)$. The data analyzed using SPSS 23.0 package program. The results of the analysis show that all sub-dimensions of authentic leadership (self-awareness, relational transparency, balanced processing and internalized moral perspective) reduce work stress in employees. The research findings are of interest to managers in the tourism sector. In addition, the findings obtained as a result of this research will be a resource for the research in hotel industry.
\end{abstract}

Keywords: Leadership, Authentic Leadership, Job Stress.

\section{$\ddot{O} \mathbf{z}$}

Kovid-19 pandemisi ile beraber turizm sektöründe yaşanan belirsizlikler, çalışanlar üzerinde önemli bir stres kaynağı oluşturmuştur. Hizmet kalitesini artırmak ve örgütsel başarıyı sağlamak için çalışanlarda oluşan bu stresin azaltılması gerekmektedir. Araştırmada, bu tür kaotik ortamlarda çalışanlarını motive etmeyi başaran otantik liderliğin, iş stresi üzerindeki etkisi araştırılmıştır. Araştırma amacına uygun olarak Alanya'daki otel çalışanlarına anket uygulaması yapılmıştır $(n=311)$. Elde edilen veriler SPSS 23.0 paket programı kullanılarak analiz edilmiştir. Analiz sonuçları otantik liderliğin tüm alt boyutlarının (öz farkındalık, ilişkisel şeffaflık, bilgiyi dengeli değerlendirme, içselleştirilmiş ahlak anlayışı) çalışanlarda iş stresini azalttığını göstermektedir. Araştırma bulguları, turizm sektöründeki yöneticilerin ilgisi çekecek niteliktedir. Ayrıca araştırma sonucunda elde edilen bulgular, otelcilik sektörüne yönelik yapılacak olan çalışmalara kaynak niteliği taşımaktadır.

Anahtar kelimeler: Liderlik, Otantik Liderlik, İş Stresi.

\footnotetext{
${ }^{1}$ Dr., Milli Savunma Üniversitesi, muratsagbass@ gmail.com, Orcıd: 0000-0001-5179-7425, (Sorumlu yazar)

${ }^{2}$ Dr. Beykent Üniversitesi, cmkarabal@gmail.com, Orcid: 0000-0001-5179-7425

${ }^{3}$ Dr., European Leadership University, lutfi.surucu@ elu.edu.tr, Orcid: 0000-0002-6286-4184
}

Makale Türü: Araştırma Makalesi - Geliş Tarihi: 18.12.2020 - Kabul Tarihi: 06.06.2021

DOI:10.17755/esosder.842877

Attf için: Elektronik Sosyal Bilimler Dergisi, 2021;20(79): 1328-1340

Bu çalışmanın araştırma verileri 2019 yılında toplanmıştır. 


\section{INTRODUCTION}

With the globalization the rapid changes in the world order necessitated many innovations. Leaders, who are the main actors of the business world, came to the fore at the beginning of these innovations and businesses started to sign important transformations with the changing leadership understanding. With the positive changes in almost every field of the business, the implementation of the creative and production-based innovations of the business life and the creativeization of the employees through in-house training started to attract attention. In the researches, it was observed that the visionary leaders who used the creative power of the global understanding in the 21 st century were more effective. Aware of this, the business world targets leaders with visionary global understanding in order not to make mistakes about new managerial searches (Değirmenci, 2012). In the process where change is inevitable, needs increase and diversify very quickly. Enterprises trying to meet the increasing and diversifying consumer needs have to renew themselves. In order for businesses to survive in competitive market conditions, replacing oppressive and over-controlling leaders; reveals the needs of a new generation of leaders, who can easily adapt to change, know their own shortcomings and strive to complete, exchange ideas with their subordinates and raise their subordinates. These developments have brought new insights into the business world and literature, instead of known leadership approaches. "Authentic leaders are wanted!" By Bill George, former manager of Medtronic, a major American company. The call was made as a result of corporate scandals. According to George, there is a need for authentic leaders who are committed to creating ethical and sustainable institutions (George, 2003). We think that the authentic leadership style will have an important contribution in reducing the level of stress in businesses, apart from defining a unique, sincere employer and manager. In this context, the purpose of the study is to investigate whether there is a relationship between authentic leadership and job stress and to analyze it with an exemplary application and to reveal its results.

\section{LITERATURE REVIEW AND HYPOTHESES}

In literature studies, it is seen that the relationship between many concepts related to job stress, especially performance, is examined (Tunç and Çelik, 2010) and the factors affecting work stress are tried to be measured. Although there are multiple sources of stress experienced by employees in the workplace, it is observed that the number of managers who do not know their subordinates and cannot empathize with the increasing competition conditions. At this stage, the close relationship between stress in the workplace and the concept of leadership emerges. In studies on the concept of leadership, researchers have tried to explain leadership by highlighting different characteristics such as "feature", "process", "interaction", "power relationship", "aspects of management", "effectiveness" (Yukl and Portugal, 1994). In these concepts; It shows the relationships between the job, the employee and the leader and reveals the effects of the leader on the stress that will occur in the workplace.

Authentic leaders, the subject of our study, are leaders who have positive characteristics such as trust, transparency, organizational commitment with their environment, job satisfaction, and taking responsibility that they develop and maintain in the organizational environment (Hassan and Forbis, 2011). One of the biggest factors in front of these positive results that are desired to be seen in the work environment is work stress. Today, the stress that managers experience due to high performance expectations and employees obligation to deal with many business and non-work problems are frequently brought to the agenda (Voki and Bogdani, 2007). With this study, it is thought that the positive effect of authentic leadership on job stress will be determined and the results will contribute to the literature. In 
addition, the results obtained will serve as a source for hotel business employees, managers and organizations to resolve their problems. The lack of sufficient work on authentic leadership and business stress and the fact that these issues are not applied to hotel businesses can be seen as a deficiency in this area.

\subsection{Authentic Leadership}

In today's approaches, where definitions and expectations regarding leaders differ, one of the modern leadership styles developing is authentic leadership. The philosophical meaning of the word authentic; While it is historically related to individual virtues and ethical behavior, it is stated that it is related to individual characteristics and identities in terms of psychological meaning (Novicevic et al., 2005). Authentic leaders understand personal differences and attach great importance to this (Kıcır and Paşaoğlu, 2014). Leadership plays a vital role in the implementation of strategies (Sürücü and Şeşen, 2019; Şeşen et al., 2019). In the business world, which has become competitive and dynamic today, it has increased the importance of leaders who have to make change (Sürücü et al., 2020). Because in order to survive in this competitive and change environment and to compete and become better, it is necessary to make radical changes and innovations (Eren, 2010: 461; Sürücü and Şeşen, 2019). Authentic leadership refers to a process that is open with the followers of the authentic leader, that is based on transparency, in other words, that allows its followers to access information about him and is based on interaction with the follower (Kıcir and Paşaoğlu, 2014; Sürücü et al., 2020). Authentic leaders are those who know all aspects of their personal positive or negative, are not content with the present, are based on their values, principles and beliefs, and are ultimately in an effort to move forward (Ilies et al., 2005). Authentic leaders can make a fundamental difference in organizations with their greater self-awareness (Avolio and Gardner, 2005).

Skill capacity is crucial for authentic leaders. Their capacity, which directly affects their work, increases with time and experience gains. Harter (2002), explains the concept of authenticity as a process based on thought, need, emotion, desire, priority or "self-knowledge" depending on one's own experiences (Avolio and Gardner, 2005). As stated in this definition, one's experience and self-knowledge are an important parameter for authentic leadership. Authentic leaders are honestly known and respected people who know what they believe and who they are, show consistency and transparency among ethical judgment, value judgments, and attitudes, focus on developing a positive mood such as trust, optimism and flexibility among themselves and their colleagues (Avolio et al., 2004). Authentic leaders act in line with their beliefs and deep personal values in order to build reputation and gain the respect and trust of their followers. Thanks to this management way, they are recognized as authentic leaders by their followers. According to George (2003), authentic leaders really strive to serve other people with leadership. They endeavor to empower people they manage to make a difference. In addition, they try to equip the people they rule with characteristics such as passion, compassion and conscience as well as logic (Kıcır and Paşaoğlu, 2014). Authenticity is essential in terms of employees development, well-being and self-awareness (Ilies et al., 2005). As a matter of fact, leaders and employees in authentic institutions are working to unleash each other's development potential (Novicevic et al., 2005). The concept of authentic leadership is structured in four dimensions by Walumbwa et al. (2008) as self-awareness, relational transparency, prejudice evaluation and internalized moral understanding.

\section{Self-Awareness}

Authentic leaders are leaders who, unlike other leaders, choose to connect more with their followers and get feedback from them. During this communication, they try to be more natural, unlike leaders like charismatic leaders. They do not try to impress their followers with 
charismatic traits or highly motivating speeches. They are not afraid of criticism and even when making mistakes against them. Their goal is to learn their strengths and weaknesses and to be aware of them (Walumbwa et al., 2008).

\section{Relational Transparency}

Since authentic leaders are sincere leaders who accept their mistakes, they express exactly what they want to express in plain language. Although they are transparent in explaining their feelings and feelings to their followers, they make the necessary arrangements to eliminate inappropriate situations and conditions (Gardner et al., 2005). Employees, who know and feel that the relationships are sincere and transparent, express themselves more comfortably to the leader and transfer the problems they experience in the organization to the leader for a correct solution. As a result, decision-making processes and a positive moral climate that encourage the establishment of transparent relationships and create trust and loyalty within the organization are considered to contribute to a successful business environment.

\section{Prejudicial Evaluation}

Unlike most leaders, authentic leaders do not endeavor to adopt their own views and thoughts to their followers. They try to ensure that their followers express their ideas freely with a sincere approach. While they encourage them for new and original ideas, they convince their followers that they have an unbiased perspective. It was observed that leaders with sufficient self-confidence evaluated the information they obtained in their followers with less bias than leaders with low or high self-confidence (Kernis 2003). Information evaluated with less bias will increase the credibility of decisions, and will provide trust in the followers' view of the leader.

\section{Internalized Ethics}

The fact that authentic leaders have an internalized moral outlook creates the need for them to set their own internal ethical standards within society and in front of their followers. However, this regulation should not mean that the leader does not interact with his followers. Examining, developing and evaluating the relationships established by the leader and the messages received from the society and evaluating them with some internal values and standards constitute an important source in the emergence and formation of the internalized moral understanding. Although there is an understanding of morality defined as internalized, the formation of this understanding depends on external factors. Authentic leaders do not have these characteristics from birth. They try to improve themselves and fill their deficiencies with the feedback they receive from their followers and society (George, 2003).

\subsection{Job Stress}

Although more used in disciplines to protect physical and mental health, the term stress has found itself a place in many areas from political sciences to business, from economy to education and has become a concept used by almost everyone in daily life (Korkmaz et al., 2015; Sürücü et al., 2020). There are many dangers threatening employees in different parts of industrial life. Stress is another important threat that affects thousands of people as effectively, quietly and invisibly as well as occupational accidents and occupational diseases at workplaces (Sabuncuoğlu and Vergiliel, 2013). Stress is a dynamic situation where the individual encounters an opportunity, demand or resource about what he desires and does not perceive that his result is both ambiguous and important (Robbins and Judge, 2013). Various forms of stress arising from many factors such as business life and complexity of daily life have been defined. Factors affecting the formation of stress may be related to individual, business environment or general environment (Eren, 2012). Job stress prevents 
employees from performing their main duties and causes them to react both physically and mentally (Cam, 2004). Stress fed from individual and organizational sources confronts employees with a number of physical and mental health problems. A healthy organization and management structure is required for the employees to cope with the stress they experience (Gül, 2007; Sürücü and Şeşen, 2019). It is stated that job stress also has a significant impact on employees' intention to quit (Helen et al., 2009). For example, when experienced intensely and for a long time; While it has some harmful consequences that may arise on the individual, it causes a decrease in performance, loss of sense of belonging of the employee and alienation to the environment (Bayram, 2006).

\subsection{The Effect of Authentic Leadership on Job Stress}

One of the causes of stress caused by the factors related to the work environment that emerges on the employees may arise from the relationship between the employee and the employer or the manager. Employees can be stressed, especially due to differences in leadership styles. In the researches, evaluations are made based on the fact that the leader is directed towards the employee or the leader is directed towards production, and work stress is considered as a possible outcome especially for those working under the production oriented leadership styles.

From employee-oriented leadership behaviors; employee support behavior, coaching behavior, counseling behavior, appreciation and rewarding behavior are related to the job stress on the employee (Ergün and Çelik, 2015). Leaders, who convince employees, communicate effectively with them, motivate them and prepare them for change play a key role in reducing their job stress levels by providing efficiency and organizational synergy in their businesses (Ergin and Özbek, 2017). Today, it is said that the relations of employees with their managers and destructive management practices are among the primary sources of stress (Aksay and Güğerçin, 2016). In a study by Rahimnia and Sharifirad (2015), it was found that authentic leadership mediated the relationship between perceived stress and stress symptoms. Another study concluded that authentic leadership is an important factor in reducing work stress (Weiss et al., 2018). In some studies that reverses the findings here, no significant relationships were found between authentic leadership and job stress due to the situations arising from the sample (Dar et al., 2016).

Within the scope of this study, there is a relationship between authentic leadership and job stress and the idea that this will be negative. In this context, the research model and hypotheses have been developed between the sub-dimensions of authentic leadership and the single dimension of work stress as follows: 


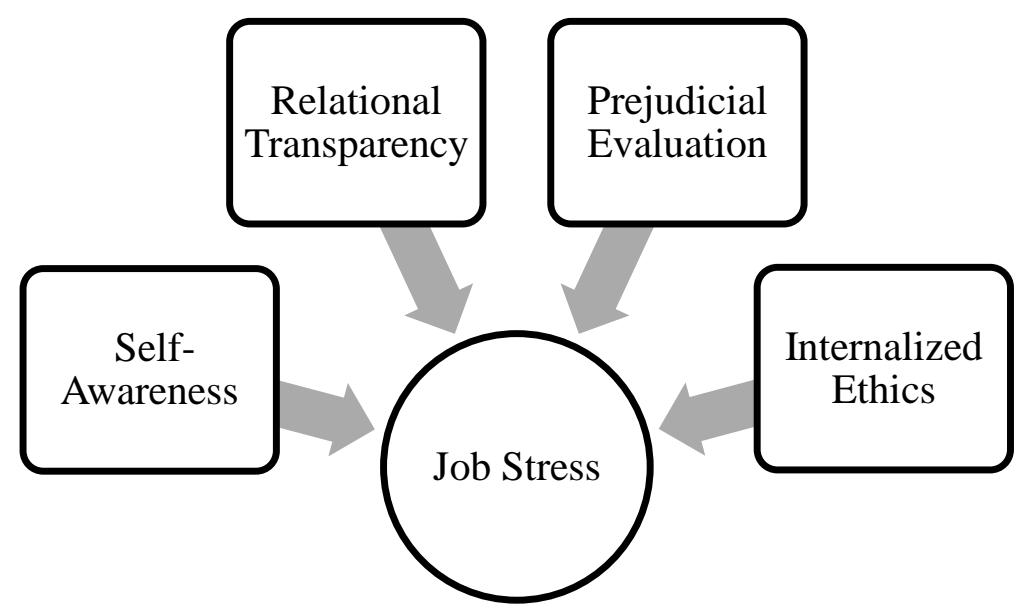

Figure 1 Research Model

\section{Self-Awareness}

Authentic leaders are leaders who choose to engage more and get feedback from their followers. They do not try to impress their followers with charismatic traits or highly motivating speeches. Their goal is to learn their strengths and weaknesses and to be aware of them (Walumbwa et al., 2008). There is a significant and negative relationship between the self-awareness sub-dimension of authentic leadership and job stress.

\section{H1: Self-awareness dimension of authentic leadership negatively affects job stress.}

\section{Relational Transparency}

Since authentic leaders are sincere leaders who accept their mistakes, they express exactly what they want to express in plain language. Although they are transparent in explaining their feelings and feelings to their followers, they make the necessary arrangements to eliminate inappropriate situations and conditions (Gardner et al., 2005). Decision-making processes that encourage transparent relationships and create trust and loyalty within the organization and a positive moral climate are considered to contribute to a successful business environment. (Ünlü, 2009). There is a significant and negative relationship between the relational transparency sub-dimension of authentic leadership and job stress.

\section{H2: Relational transparency dimension of authentic leadership negatively affects job stress.}

\section{Prejudicial Evaluation}

While authentic leaders encourage their followers for new and original ideas, they convince their followers that they have an unbiased perspective. In addition, it was observed that leaders with sufficient self-confidence evaluated the information they obtained in their followers with less bias than leaders with low or high self-confidence (Kernis 2003). Information evaluated with less bias will increase the credibility of decisions, and will provide trust in the followers' view of the leader. There is a significant and negative relationship between the prejudicial evaluation sub-dimension of authentic leadership and job stress.

H3: Prejudicial evaluation dimension of authentic leadership negatively affects job stress. 


\section{Internalized Ethics}

The fact that authentic leaders have an internalized moral outlook creates the need for them to set their own internal ethical standards within society and in front of their followers. However, this regulation should not mean that the leader does not interact with his followers. Examining, developing and evaluating the relationships established by the leader and the messages received from the society and evaluating them with some internal values and standards constitute an important source in the emergence and formation of the internalized moral understanding. Although there is an understanding of morality defined as internalized, the formation of this understanding also depends on external factors. There is a significant and negative relationship between the internalized ethics sub-dimension of authentic leadership and job stress.

\section{H4: Internalized ethics dimension of authentic leadership negatively affects job stress.}

\section{METHOD}

\subsection{Data Collection and Sample}

With its labor-intensive nature, hotels are sectors where work stress is intense. For this reason, five-stars hotel staff in Alanya/Turkey was chosen as the research population. For this purpose, the managers of the hotels were interviewed and permission was asked to conduct research. Provided that the research data is not shared with third parties and the hotel name is not specified, closed-envelope questionnaires (150 questionnaires for each hotel) were delivered to the human resources managers of the 3 hotels that allowed the research to be conducted, and the questionnaires filled in again in closed envelopes were received. 311 questionnaires available were obtained in the study conducted with the easy sampling method. The research was conducted in 2019. Since the tourism sector employs temporary workers seasonally and is a sector associated with high turnover, there is no reliable information about the sample size. Therefore, it is not possible to clearly state whether the sample number $(n=311)$ represents the universe or not.

Of the participants, 145 are women, 166 are men, 92 are married and 219 are single. When the age group of the sample group is examined; 12 participants are aged 41 and over, 15 participants are between 36-41 years old, 42 participants are between 31-35 years old, 96 participants are between 26-30 years old, 146 participants are 25 years old and below. When the education levels are examined; it is seen that 162 participants have the undergraduate and graduate education levels, 41 participants have the associate degree level and 108 have high school education and under level.

\subsection{Measures}

In the research, a questionnaire form consisting of three parts was used.

Demographic factors: There are five items to determine the age, gender, marital status, education level and work experience of the participants.

Authentic Leadership: The authentic leadership scale, which was developed and analyzed by Walumbwa et al. (2008) using five different samples obtained from China, Kenya and the USA, was adapted to Turkish by Tabak et al. (2012). The scale prepared in the type of five Likert. It consists of four sub-dimensions: self-awareness, relational transparency, balanced processing and internalized moral perspective. Sample questions of the scale: "My manager's thoughts and behaviors are consistent." and "My manager clearly says what he meant." Cronbach's Alpha value of the scale was measured as .911. Cronbach's Alpha value of the sub-dimensions of the scale was measured as .732, .723, .805, .791. Tabak et al. (2012) 
determined the reliability values of their scales as $.90, .86, .85$ and .83 , respectively, in their study.

Job stress: To measure employee stress, Cohen et al. (1983) and adapted to Turkish by Küçükusta (2007), the scale was used. There are four items in 5-point Likert type in the scale. Sample questions of one-dimensional scale developed, "I get angry and uncomfortable with the work done here." and "If I had a different job, my health would be better." Cronbach's Alpha value of the scale was measured as .822. Küçükusta (2007) determined the reliability value of the work stress scale as .763 in his research.

The Cronbach's Alpha values of the variables included in the study are .7 and above, which is the lower threshold value suggested in the literature. The values obtained show that there is consistency of the scales (Sürücü et al., 2021).

\subsection{Research Findings}

SPSS 23.0 for Windows package program was used to test the model created within the scope of the research. First of all, descriptives and frequency analyzes were carried out to determine the demographic characteristics of the participants. Reliability analyzes were conducted to test the reliability of the scales used in the research (Table 1). Pearson correlation analyzes were conducted to determine the relationships of variables with each other and regression analyzes were conducted to test the hypotheses (Table 2).

Before testing the research hypotheses, the validity and reliability of the scales in the research were tested. In order to analyze the structural validity of the scales, exploratory factor analysis was performed using the Varimax technique, which is one of the orthogonal rotation techniques of Principle Component Analysis and Principle Component Analysis. As a result of the analysis, the fact that the Kaiser Meyer Olkin (KMO) test results (authentic leadership: 0.879, Work Stress: 0.796) are greater than 0.7, the sample size is sufficient and the result of the Barlett sphericity test (authentic leadership: X2 (36) $=814.804, \mathrm{p}<0.001$, Job Stress: X2 $(6)=390.307, \mathrm{p}<0.001)$ indicates that the correlation relationship between the expressions of the variables included in the study is suitable for factor analysis (Tabachnick and Fidell, 2007).

In the factor analysis made for Authentic leadership, taking into account the variances explained by the factors, it was ensured that a factor with an eigenvalue greater than 1 was created and thus it was seen that a four-factor structure would be appropriate. The factor loads of the items are .510 and above (Table 1). Considering the variances explained by the factors in the factor analysis made for work stress, it was observed that a factor with an eigenvalue greater than 1 was created and thus a single-factor structure would be appropriate. The factor loads of the items are .643 and above (Table 1).

Analysis results to determine the reliability of the scales (Table 1) show that the internal consistency coefficients ( $\alpha$ and $\mathrm{Cr}$ ) of the scales have a good reliability above 0.70 (Mackenzie, Podsakoff and Podsakoff, 2011; Sürücü et al., 2021). 
Table 1. Reliability Values of the Scales

\begin{tabular}{lcccc}
\hline \multicolumn{1}{c}{ Variables } & $\begin{array}{c}\text { Item } \\
\text { Number }\end{array}$ & $\begin{array}{c}\text { Factors } \\
\text { Loading }\end{array}$ & $\begin{array}{c}\text { Croanbach } \\
\text { Alfa (a) }\end{array}$ & $\begin{array}{c}\text { Discriminant } \\
\text { validity (Cr) }\end{array}$ \\
\hline Self-Awareness & 4 & $.562-.711$ & .732 & .752 \\
Relational Transparency & 5 & $.510-.722$ & .723 & .743 \\
Balanced Processing & 4 & $.597-.821$ & .805 & .785 \\
Internalized Moral Perspective & 3 & $.589-.652$ & .791 & .797 \\
Job Stress & 4 & $.643-.809$ & .822 & .820 \\
\hline
\end{tabular}

The distribution of data is important in determining statistical analysis methods. Skewness and kurtosis values were taken into consideration to determine the distribution of the data. In the analysis made, it was determined that there are skewness $=-.052$, kurtosis $=$, 678 for authentic leadership, and skewness $=-.464$, kurtosis $=-.283$ for work stress. These values are between +1.5 and -1.5 , which are generally accepted in the literature, and show that it has a given normal distribution (Hair et al., 1998). For this reason, the Pearson correlation coefficient was taken into account in the correlation analysis.

The descriptive statistic and correlations results of the scales included in the study are presented in Table 2.

Table 2. Descriptive Statistic and Correlations

\begin{tabular}{|c|c|c|c|c|c|c|c|}
\hline \multirow{2}{*}{ Variable } & \multicolumn{5}{|c|}{ Correlations } & \multirow{2}{*}{$\mathbf{M}$} & \multirow{2}{*}{ SD } \\
\hline & $\mathbf{1}$ & 2 & 3 & 4 & 5 & & \\
\hline 1. Self-Awareness & 1 & & & & & 3.54 & .817 \\
\hline 2. Relational Transparency & $.328 * *$ & 1 & & & & 3.71 & .785 \\
\hline 3. Balanced Processing & $.212 * *$ & $.324 * *$ & 1 & & & 3.26 & .721 \\
\hline $\begin{array}{l}\text { 4. Internalized-Moral } \\
\text { Perspective }\end{array}$ & $.555^{* *}$ & $.409 * *$ & $168 * *$ & 1 & & 3.43 & .769 \\
\hline 5. Job Stress & $-.178 * *$ & $-.167 * *$ & $-.127 * *$ & $-.309 * *$ & 1 & 2.98 & 1.001 \\
\hline
\end{tabular}

$* * \mathrm{p}<0,05$,

Table 2 shows the results of the correlation analysis of the variables. All the subdimensions of authentic leadership have a significant and negative correlation with job stress. Correlation of sub-dimensions of authentic leadership with job stress, respectively: selfawareness $r=-178, \mathrm{p}<.05$, relational transparency $r=-167, \mathrm{p}<.05$, balanced processing $r=-$ $127, \mathrm{p}<.05$ and internalized morale perspective $r=-309, \mathrm{p}<.05$. Therefore, the highest correlation with work stress is with internalized moral perspective $(r=-309, p<.05)$.

The literature states that demographic variables such as age, gender, and marital status are associated with job stress (Kirpik, 2020; Yücel et al., 2019). For this reason, in order to understand the effect of authentic leadership on job stress more clearly, the effect of 
demographic variables on job stress has been controlled in regression analysis. In the first stage of hierarchical regression analysis, demographic variables (gender, age and marital status) were taken under control (Model 1) and in the second stage, dependent variables were included in the model (Model 2). The regression analysis results are presented in Table 3

Table 3. Hypothesis Tests (Regression Results)

\begin{tabular}{lll}
\hline \multirow{2}{*}{ Variables } & \multicolumn{2}{c}{ Job Stress } \\
\cline { 2 - 3 } & Model 1 & Model 2 \\
\hline Self-Awareness & & $-.174 * *$ \\
Relational Transparency & $-.202 * *$ \\
Balanced Processing & & $-.399 * * *$ \\
Internalized Moral Perspective & $-.221 * *$ \\
\hline $\mathrm{F}$ & .867 & $6.521 * * *$ \\
$\mathrm{R}^{2}$ & .009 & .143 \\
\hline$* \mathrm{p}<0.1, \quad * * \mathrm{p}<0.05, \quad * * * \mathrm{p}<0.001$ & &
\end{tabular}

When Table 3 is examined: self-awareness $(\beta=-.174, p<.05)$, relational transparency $(\beta$ $=-.202, p<.05)$, balanced processing $(\beta=-.399, p<.001)$ and internalized moral perspective $(\beta=-.221, p<.05)$ appear to affect job stress significantly and negatively. Thus, balanced processing $(\beta=-.399, p<.001)$, one of the sub-dimensions of authentic leadership, is the dimension that has the greatest impact on job stress. In the light of the findings, the hypothesis 1 , hypothesis 2 , hypothesis 3 and hypothesis 4 of the study were accepted.

\section{CONCLUSIONS}

When the research results are examined, within the relevant sample, the subdimensions of authentic leadership; self-awareness, relational transparency, assessment without prejudice and internalized moral understanding have been shown to support hypotheses and have a negative relationship with work stress. The findings obtained in the research show parallelism with the study findings of Sultana et al. (2020) and Ismail et al. (2019). However, our research expands on past research findings by examining the effect of authentic leader on job stress in the context of tourism.

The tourism industry has a dynamically functioning and labor intensive basis. The sector workers, who try to create value for their customers in such environments, can work under high stress under the pressure of unit managers. Employees who already feel heavily in order to avoid losing their jobs in the sector, where seasonal work is intense, increase their work stresses from time to time when they are also exposed to customer and executive pressure. This situation directly reflects on their service and affects even the customer side negatively. In environments with authentic leaders, more transparent, more prejudiced valuations and a high level of moral understanding are observed. Research results support this view. For the employees, the specific actions of the managers in the sector, their objective approaches together with the comprehensive evaluations, the right, honest and fair behavior to them, decreases the level of work stress. Leaders may prefer to be as interactive as they can in reaching the goal of the business, they should also be transformative when necessary, but they should not forget that; more authenticity results in less work stress. Therefore, they should not ignore the fact that they can be more successful with natural and unique actions instead of taking a hard attitude with different actions than they are. In addition, considering the uncertainties about the sector for the Covid-19 pandemic and its aftermath that has seriously hit the tourism sector, there is a need for leaders to manage not only customers but also all 
employees. Therefore, authentic leadership will enable them to motivate their followers in achieving the goal in such chaotic environments and to reduce the size of the work stress they have already placed.

In the research, the effect of authentic leadership on work stress was evaluated and some advice was given to the practitioners. The research that contributes to the literature has some limitations. The study was carried out only in hotel businesses operating in the tourism sector in Alanya/Turkey. Therefore, the sample size of the study is limited. In addition, more research can be done to test and generalize findings at different time intervals, at various hotels and in different places. Finally, in future studies, different data collection techniques can be used to obtain more information and data collection time can be kept longer.

\section{References}

Aksay, B., \& Güğerçin, U. (2016). Yıkıcı yönetimin izlenim yönetimi taktikleri üzerindeki etkisi: Beyaz yakalı çalışanlar üzerine bir araştırma, Ç.Ü. Sosyal Bilimler Enstitüsü Dergisi, 25(3), 441-456.

Avolio, B. J., \& Gardner, W. (2005). Authentic leadership development: Getting to the root of positive forms of leadership, The Leadership Quarterly, 16(3), 315-338.

Avolio, B. J., Gardner, W. L., Walumbwa, F. O., Luthans, F., \& May, D. R. (2004). Unlocking the mask: A look at the process by which authentic leaders impact follower attitudes and behaviors, The Leadership Quarterly, 15(6), 801-823.

Bayram, S. (2006). Örgütsel stres faktörleri ve rehber ögretmenler üzerinde bir uygulama, Yüksek Lisans Tezi, Kocaeli Üniversitesi Sosyal Bilimler Enstitüsü, Kocaeli.

Cam, E. (2004). Çalışma yaşamında stres ve kamu kesiminde kadın çalışanlar, Uluslararası Insan Bilimleri Dergisi, 1(1), 1-10.

Cohen, S., Kamarck, T., \& Mermelstein, R. (1983). A global measure of perceived stress, Journal of Health and Social Behavior, 385-396.

Dar, F., Bukharı, I., \& Hamid, M. (2016). Relationship between authentic leadership, work engagement and job stress among employees of telecommunication organizations, Peshawar Journal of Psychology and Behavioral Sciences, 2(2), 235-248.

Değirmenci, H. (2012). 21. Yüzyılda Liderlik ve Işs Dünyası, İstanbul: Bilge Karınca Yayınları.

Eren, E. (2010). Stratejik yönetim ve işletme politikası, İstanbul: Beta Yayınları.

Eren, E. (2012). Örgütsel davranış ve yönetim psikolojisi (12. Basım), İstanbul: Beta Yayınları.

Ergin, H., \& Özbek, A. (2017). Katılımcı liderlik anlayışının stres yönetimine etkisi International Congress on Afro - Eurasian Research I1 (S. 91-105). Malaga: AfroEurasian Research.

Ergün, E., \& Çelik, S. (2015). Yöneticilerin görev ve çalışan odaklı liderlik davranışları ve hemşirelerin iş tatmini, örgütsel bağlılı̆̆ ve iş stresi arasındaki ilişki, F.N. Hemşirelik Dergisi, 23(3), 203-214.

Gardner, W. L., Avolio, B.J. \& Walumbwa, F.O. Eds. (2005). Authentic leadership theory and practice: Origins, effects and development Oxford, UK: Elsevier Science.

George, B. (2003). Authentic leadership: Rediscovering the secrets to creating lasting value, San Francisco: Jossey-Bass. 
Gül, H. (2007). İş stresi, örgütsel sağlik ve performans arasındaki ilişkiler: Bir alan araştırmas1, Karamanoğlu Mehmetbey Üniversitesi Sosyal ve Ekonomik Araştırmalar Dergisi, 318-332.

Hair, J. F., Black, W. C., Babin, B. J., Anderson, R. E., \& Tatham, R. L. (1998). Multivariate data analysis (Vol. 5, No. 3, pp. 207-219). Upper Saddle River, NJ: Prentice hall

Hassan A, Forbis A (2011) Authentic leadership, trust and work engagement. World Academy of Science, Engineering and Technology 80: 750-756.

Helen, K., Catherine, K., \& Christine, K. (2009). The importance of job satisfaction and organizational commitment in shaping turnover intent: A test of a causal model, Journal of The International Society for The Investigation of Stress, 34(1): 397-404.

Iles, R., Morgeson, F., \& Nahrgang, J. (2005). Authentic leadership and eudaemonic wellbeing: understanding leader-follower outcomes, The Leadership Quarterly, 16(3), 373-394.

Ismail, S. N., Abdullah, A. S., \& Abdullah, A. G. K. (2019). The effect of school leaders' authentic leadership on teachers' job stress in the eastern part of peninsular Malaysia. International Journal of Instruction, 12(2), 67-80.

Kernis, M. H., (2003). Target Article: Toward a Conceptualization of Optimal Self-Esteem, Psychological Inquiry, 14:1, 1-26.

Kıcır, G., \& Paşaoğlu, D. (2014). Otantik liderliğin akademik platformda lider boyutu açısından incelenmesi, Eskişehir Osmangazi Üniversitesi Sosyal Bilimler Dergisi, 15(1), 1-24.

Kirpik, G. (2020). Serbest Eczacıların İş Stres Düzeylerinin Belirlenmesi Ve Bazı SosyoDemografik Özellikler Açısından İncelenmesi: Adıyaman Örneği. R\&S-Research Studies Anatolia Journal, 3(4), 306-320.

Korkmaz, M., Germir, H. N., Şahbudak, E., Şen, E., Gürkan, A., \& Kuzucuoğlu, A. H. (2015). Stres performans verimlilik, İstanbul: Çatı Yayınları.

Küçükusta, D. (2007), Konaklama İşletmelerinde İş-Yaşam Dengesinin Çalışma Yaşamı Kalitesi Üzerindeki Etkisi, Yayımlanmamış Doktora Tezi, İzmir.

Küçükusta, D. (2007). Konaklama işletmelerinde iş-yaşam dengesinin çalışma yaşamı kalitesi üzerindeki etkisi, Doktora Tezi, Dokuz Eylül Üniversitesi, İzmir.

Mackenzie, S. B., Podsakoff, P. M., \& Podsakoff, N. P. (2011). Construct measurement and validation procedures in MIS and behavioral research: Integrating new and existing techniques. Mis Quarterly, 35(2), 293-334.

Novicevic, M. M., Davis, W., Dorn, F., Buckley, M., \& Brown, J. (2005). Barnard on conflicts of responsibility: Implications for today's perspectives on transformational and authentic leadership, Management Decision, 43(10), 1396-1409.

Rahimnia, F., \& Sharıfirad, M. S. (2015). Authentic leadership and employee well-being: The mediating role of attachment insecurity, J Bus Ethics, 132(2): 363-377.

Robbins, S. P., \& Judge, T. A. (2013). Örgütsel Davranış (Organizational Behaviour 14. Basımdan Çeviri), Ankara: Nobel Yayınları

Sabuncuoğlu, Z., \& Vergiliel, T. M. (2013). Örgütsel Davranış, Bursa: Alfa Aktüel. 
Şeşen, H., Sürücü, L., \& Maşlakc1, A. (2019). On the relation between leadership and positive psychological capital in the hospitality industry, International Journal of Business, 24(2), 183-16.

Sultana, U. S., Tarofder, A. K., Darun, M. R., Haque, A., \& Sharief, S. R. (2020). Authentic leadership effect on pharmacists job stress and satisfaction during COVID-19 pandemic: Malaysian perspective. Talent Development \& Excellence, 12(3).

Sürücü, L., \& Şeşen, H. (2019). Entrepreneurial behaviors in the hospitality industry: Human resources management practices and leader member exchange role, Revista De Cercetare Si Interventie Sociala, 66(1), 115-118.

Sürücü, L., \& Şeşen, H., \& Maslakçı, A. (2020). SPSS, AMOS ve PROCESS Macro ile İlişkisel, Aracı / Düzenleyici ve Yapısal Eşitlik Modellemesi Uygulamalı Analizler, Detay Yayınc1lık.

Sürücü, L., Maşlakc1, A., \& Şeşen, H. (2020). The role of positive psychological capital in the effect of leadership styles on organizational commitment: A study of hospitality services, African Journal of Hospitality, Tourism and Leisure, 9(2), 1-4.

Tabachnick, B. G., Fidell, L. S. \& Ullman, J. B. (2007). Using multivariate statistics (Vol. 5). Boston, MA: Pearson.

Tabak, A., Polat, M., Coşar, S., \& Türköz, T. (2012). Otantik liderlik ölçeği: güvenirlik ve geçerlik çalışması. ISGUC The Journal of Industrial Relations and Human Resources, 14(4), 89-106.

Tunç, Ö., Çelik, M., (2010). Çalışanların Algıladıkları Örgütsel Destek ve İş Stresinin Örgütsel Özdeşleşmeye ve İş Performansına Etkisi. Yönetim ve Ekonomi Dergisi, 17(2), 184-206.

Voki, N., Bogdani, A., (2007). Individual Differences and Occupational Stress Perceived: A Croatian Survey. Working Paper Series, Paper No: 5-7.

Walumbwa, F. O., Avolio, B. J. , Zhu, W. (2008). "How Transformational Leadership Weaves Its Influence on Individual Job Performance: The Role of Identification and Efficacy Beliefs", Personnel Psychology, 61: 793-825.

Walumbwa, F., Avolio, B., Gardner, W., Wensing, T., \& Peterson, S. (2008). Authentic leadership: Development and validation of a theory-based measure, Journal of Management, 34(1), 89-126.

Weiss, M., Razınskas, S., Backmann, J., \& Hoegl, M. (2018). Authentic leadership and leaders' mental well-being: an experience sampling study, The Leadership Quarterly, 29(2), 309-321.

Yapraklı, Ş., \& Yılmaz, M. K. (2007). Çalışanların iş stresi algılarının iş tatminleri üzerindeki etkisi: Erzurum'da ilaç mümessilleri üzerinde bir saha araştırması, Ikktisadi ve İdari Bilimler Dergisi, 21(1), 155-183.

Yücel, A. S., Orhan, S., Şekeroğlu, B., Karadağ, T. F., \& Çeviker, A. (2019). Beden Eğitimi Öğretmenlerinin Örgütsel İş Stres Düzeylerinin Bazı Demografik Değişkenler Açısından Değerlendirilmesi. Spor Eğitim Dergisi, 3(2), 58-70.

Yulk, G., \& Portugal, E. (1994). Perspectives on Enviromental Leadership, The Leadership Quarterly, 5(3-4), 271-276. 